\title{
Erratum: Infant Attachment and Social Modification of Stress Neurobiology
}

\section{Frontiers Production Office*}

Frontiers Media SA, Lausanne, Switzerland

\section{OPEN ACCESS}

Approved by:

Frontiers Editorial Office,

Frontiers Media SA, Switzerland

${ }^{*}$ Correspondence:

Frontiers Production Office

production.office@frontiersin.org

Received: 10 September 2021 Accepted: 10 September 2021

Published: 05 October 2021

Citation:

Frontiers Production Office (2021) Erratum: Infant Attachment and Social Modification of Stress Neurobiology.

Front. Syst. Neurosci. 15:773624. doi: 10.3389/fnsys.2021.773624
Keywords: attachment, amygdala, infant, corticosterone, social

\section{An Erratum on}

Infant Attachment and Social Modification of Stress Neurobiology

by Packard, K., Opendak, M., Soper, C. D., Sardar, H., and Sullivan, R. M. (2021). Front. Syst. Neurosci. 15:718198. doi: 10.3389/fnsys.2021.718198

Due to a publisher error, the Editor's note was not included in the original article; this has now been corrected.

The original article has been updated.

Copyright $\odot 2021$ Frontiers Production Office. This is an open-access article distributed under the terms of the Creative Commons Attribution License (CC BY). The use, distribution or reproduction in other forums is permitted, provided the original author(s) and the copyright owner(s) are credited and that the original publication in this journal is cited, in accordance with accepted academic practice. No use, distribution or reproduction is permitted which does not comply with these terms. 